\title{
RECEPCJA SW. AUGUSTYNA W MARIOLOGII SOBORU WATYKAŃSKIEGO II
}

Przygotowanie roboczego tekstu mariologicznego na Sobór Watykański II zlecono prezesowi Miedzynarodowej Papieskiej Akademil Maryjnej, o. Carlowi Balićowi OFH, który skonstruował dokument przede wszystkim $z$ wypowledzi zwyczajnego magisterium zwłaszcza ostatnich papiezy. Inne źródła teologiczne, wraz z Pismem św., zeszły na plan dalszy. Jego przypisy przywoływały jedynie 4 0jców Kościoła: św. Ambrożego, św. Hieronima, św. Germana z konstantynopola 1 św. Jana z Damaszḱku: dokument ten nie mspominaz św. Augustyna.

oficjalny schemat "De Beata", rozesłany Ojcom soborowym w Iistopadzie $1962 \mathrm{r}$. jako owoc długich dyskusji, którego głównym autorem by także o. Carlo Balić, ostatecznie nie wszedz pod obrady ojców, podobnie zreszta jak poprzedni, wybitnie "papieski", tzn. utkany wypowiedziami biskupów Rzymu. Odwoływaz się on do 9 Ojców w sumie 22 razy: św. Augustyn - 10, św. Ambroży 3, św. Jan z Damaszku - 3. Po jednym razie jego tekst odsyłał do sw. Andrzeja z Krety, sw. Hieronima, św. Germana z Konstantynopola, sw. Ireneuszạ, św. Justyna 1 św. Leona Wielkiego. Wzazczony został także fragment św. Augustyna z "De sancta virginitate" o tyn, że Maryja miłościaz współpracowała, by wierni rodzili sie Wościele, jak równiez myśl, że Doktor z Iippony nie chce myśleć o jakimkolwiek grzechu Maryi. Idea pierwszego tekstu woszła do Konstytucji dognatycznej o Kościele/rozdz. VIII/, mimo ze omariany tu "Schemat oficjalny" został odesłany ad acta.

W zatwierdzonym przez Sobór mariologicznym rozdziale Konstytucj1 dogmatycznej o Kościele Ojcomie Kościoła sa juź wyraźniej widoczni:

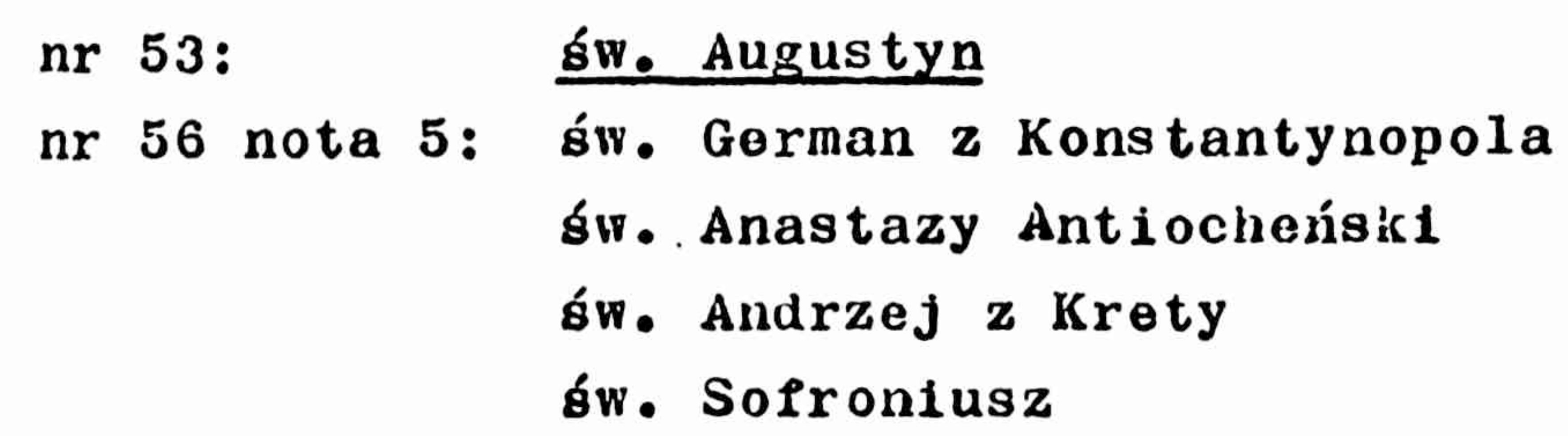

nr 56 nota 6: św. Ireneusz 
nr 56 nota 7: św. Ireneusz

nr 56 nota 8: \&w. Epifaniusz

nr 56 nota 9: śi. Hieronim

św. Augustyn

sw. Cyryl Jerozolimski

św. Jan Chryzos tom

św. Jan Darnasceński

nr 57 nota 10: św. Leon Wielki

św. Ambroży

nr 58 nota 13: 8́w. Jan Damasceńsk1

sw. German z Konstantynopola

8́w. Modest z Jerozolimy

nr 59 hota 14: 8́w. Andrzej z Krety

8́w. Jan Damasceński

nr 62 nota 15: św. Andrzej z Krety

sw. Gorman z Konstantynopola

św. Jan Damasceński

nr 62 nota 17: św. Ambroży

nr 63 nota 18: św. Ambroży

nr 63 nota 19: Pseudo-Piotr Damiani

Goteryd od św. Wiktora

Gerhoh Reich

nr 64 nota 20: św. Ambroży

św. Augustyn

św. Beda Czcigodny

św. Izaak de Stella

Latwo zauważyć równowage w powoływaniu sie na ojców Zachodu i Wschodu: 13 razy na pierwszych, 15 na drugich, w sumie "Lumen gentium" VIII powołuje sig na 15 ojców, w tym na 7 zachodnich 18 wschodnich /nadto na 4 teologów średniowiocza/.

Przyjrzyjmy sie teraz trzem miejscon, w których Sobór powołuje się na Biskupa Hippony.

\section{I}

Tekst pierwszy znajuuje sig we "Wstępie", w numerze 53, gdzie Sobór kreśli perspektywe, w która wpisuje postać Niewiasty, Matki Pana/perspektywe historiozbawcza/, Ukazując Maryje ściśle zjednoczona $z$ Bogiem z jednej strony 1 z ludźmi - z dru- 
giej. W celu podkresienia ścisłego związku z ludźmi, Sobór posłużył się słowami św. Augustyna:

"plane mater membrorum /Christi/, "zgoła matka członków/Chry/.../ quia cooperata est caritate

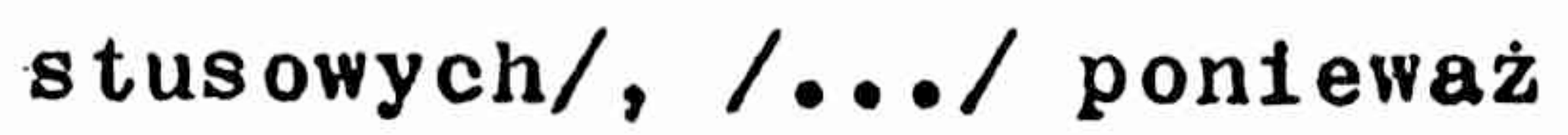
ut fideles in ecclesia nascerentur, quae llilus Capitis membra sunt". miłościa swoją współdziałała w tyı, aby wierni rodzili się w Kościele, którzy są członkami owej Głowy".

Tekst Augustyna pochodzi z "De sancta virginitate"1, w dokumencie soborowym zaś stol sanotnie w nocie 3 , bez towarzystwa innych ojców.

\section{II}

Ponownie pojawia sie Biskup Hippony w rozdziale VIII cześc1 II "Lumen gentium", która nosi tytuł "Rola Błogosławionej Dziewicy w ekonomil zbawienia". W numerze 56 rozwija sie myśl o ścisłym zwiazku Matki Najówietszej z Chrystusen, drugim Adamem i w tym kontekście sobór przywołuje,znana juz św. Ireneuszow ${ }^{2}$, patrystyczną myśl "śmierć przez Ewe, życie przez Maryję". Powołuje sie przy tym na 5 ojców: św. Hieronima ${ }^{3}$, sw. Augusty$\mathrm{na}^{4}$, św. Cyryla Jerozolimskiego ${ }^{5}$, sw. Jana Chryzostoma ${ }^{1}$ św. Jana Damasceńsiciego ${ }^{7}$.

\section{III}

Sw. Augustyn pojawia się jeszcze w rozdziale VIII części III "Lumen gentium" $w$ numerze 64. Podkreśla się tam, ze Kościóz jest jak Laryja, matka $i$ dziewica, poniewaz dochowuje "nieskazitelnie $i$ w czystości" wiary danej Chrystusowi, "a naśladując Matke Pana swego, moca Ducha Śriętego zachowuje dziewiczo niewzruszona wiare, mocna nadzieje i szczerą miłośc". Sobór odsyła

1 De sancta virginitate 6, PL 40, 399: Corpus Harianum Patristicuin, ed. Sergius Alvarez Campos, III, Burgos, 1970, nr 2850, s. 421.

2 Adversus haereses III 22,4 , SCh 211, 442-443.

3 Epistola 22, 21, PL 22, 408.

4 Sermo 51, 2, 3, PL 38, 335; Sermo 232, 2, PL 38, 1108.

5 Catechesis 12, 15, PG 33, 741, AP

6 In psalmum $44,7, P G 55,193$.

7 Homilia 2 de dormitione B. M. V. 3, PG 96, 728.' 
w tym miejscu czytelnika do św. Ambrożego ${ }^{8}$, Bedy Czcigodnego 9 i Izaaka ze stelli $i^{10}$ oraz do św. Augustyna"1 dodając: "1 In.". Jeśli pytany o treściowy wkład św. Augustyna w soborowa mariologiţ, możemy powiedzieć, że Biskup Iippony przemówił na soborze liatykaiskim II przeciwko instrumentalnej interpretacj 1 udziału kury 1 w zbawczych misteriach Chrystusa/powszechna w protestanckiej teologi niew tego udzialu. Jego słowa, że Maryja miłościa współpracowała, by wierni rodzili się w hościele, podkreślają, zo bóg nio posłuzył się Matka Najświętszą jako biernym instrumentem umożliwiającyn wcielenie, ale że udział Maryi miał charakter osobowy i osobisty, ludzki, angażujący Jej wolność. Podobnie personalistyczną treść wnosi do mariologii soborowej trzecie miejsce, do którego odwołuje się Sobór w numerze 64 Konstytucji dogmatycznej "Lumen gentium", apelując do Kościoła, by za przykładen Matki Bożej zachowywał dziewicza wierność Chrystusowi przez nienaruszona wiare, mocna nadzieje i szczera miłość.

Stanisław Celestyn Napiórkowski OFúConv - Lublin

\section{LA RECEZIONE' DI SANT'AGOSTINO \\ NELLA MARIOLOGIA DEL CONCILIO VATICANO II}

Miassunto/

Nel primitivo testo mariologico, preparato per il Concilio Vaticano II da C. Balić, Sant'Agostino completamente non appare. Nel testo "ufficiale", invece, incontriamo 9 Patri ai quali 1 'autore si riferisce 22 volte /10 volte a Sant'Agostino/. Il testo definitivo del Concilio/Lumen gentium VIII/cita 7 Padri occidentali /in totále: 13 volte/ $\theta 8$ Orientali/in totale: 15 volte/. A Sant'Agostino il testo rimanda 3 volte/ I. De sancta virginitate 6 ; II. Serwo $51,2,3$, e Sermo 232, 2 ; III. In Joannis Evangelium 13, 12 e Sermo 191, 2, 3/. L'idea "cooperata est carltate/.../", "mors per Evau, vita per Mariali" nonche 11 concetto della verginita di Maria por la fede, per la speranza e per la carita ci permette di mettere in rillevo il potente merito di Sant'Agostino per lo sviluppo del personalismo della mariologia del Vaticano II.

8 Expositio Lucae Evangelii II 7 i X 24-25, PL 15, 155511810.

9 In Lucam expositio I 2, PL 92, 330.

10 Sermo 51, PL 194, 1863 A.

11 In Joannis L'vangelium 13, 12, PL 35, 1499; Sermo 191, 2, 3, PL 38, 1010. 